\title{
Knowledge of Women About Children's Orodental Health in Their First Pregnancy: a Cross Sectional Study
}

Dana Tahririan ( D Dana_tahririan@yahoo.com )

Isfahan University of Medical Sciences

\section{Pirooz Givehchian}

Isfahan University of Medical Sciences

\section{Arezoo Eslami}

Isfahan University of Medical Sciences

\section{Research Article}

Keywords: Knowledge, Pregnancy, Mother, Oral and Dental Health, children

Posted Date: January 24th, 2022

DOI: https://doi.org/10.21203/rs.3.rs-1142182/v1

License: @ (i) This work is licensed under a Creative Commons Attribution 4.0 International License. Read Full License 


\section{Abstract}

\section{Background}

Oral health is one of the most important factors affecting the general health of the community and families; in this regard, parents, especially mothers, can play an effective role in the oral and dental health of children. This study aimed to evaluate the knowledge of pregnant women on children oral and dental health in the first pregnancy.

Methods

This cross-sectional and descriptive-analytical study was conducted on 200 pregnant women in the second and third trimesters of pregnancy referred to Obstetrics and Gynecology clinics and private offices in Isfahan-Iran from. To assess the knowledge of mothers about oral and dental health, a researcher-made questionnaire including 24 questions was used which was evaluated and verified in terms of validity and reliability. Collected data was analyzed by SPSS software version 22 using Pearson correlation coefficient and Spearman tests. The significance level was considered to be less than 0.05 .

Results

The results of this study showed that the knowledge of mothers on the oral health of the child was $8.66 \pm$ 4.53, so that their knowledge was moderate in $82(41 \%)$ and 109 (54.5\%) in poor level And $9(4.5 \%)$ were high. In addition, the relationship between mother's age $(r=0.288)$, maternal education $(r=0.497)$ and family's economic status $(r=0.182)$ with the mother's knowledge of oral health were significant $(P<0.05)$.

Conclusion

The level of knowledge of pregnant mothers on their child's oral and dental health was low, so it seems necessary to hold workshops and provide useful information before or during pregnancy.

\section{Introduction}

Since dental caries during the early years of childhood is a source of concern and an index for the unavailability of disease prevention measures in all the countries, children must observe orodental health measures [1]. Orodental health affects the quality of life, especially in young children, because it can affect growth, weight, self-confidence, socialization, and the ability to learn in children, overshadowing children's and parents' daily routines [2]. Since children's behaviors in the early years of life shape their lifestyle and attitudes during adulthood and considering the importance of deciduous teeth in children's general health, increasing breastfed children's mothers' knowledge has a pivotal role in decreasing caries rate in the community. Therefore, parents, especially mothers, have a significant role in maintaining their children's orodental health, and their knowledge can establish correct health behaviors in children [3]. The first steps to preserve a child's oral health and teeth by parents (a pregnant mother) begin during pregnancy [4], and the mother's oral health not only can affect her health and esthetic appearance during and after pregnancy, 
but also it can affect the general and dental health of the newborn baby [5]. Most studies have shown that pregnancy can increase the susceptibility to periodontal diseases and dental caries. Besides, severe gingivitis in pregnant women might be associated with adverse effects, such as increased risks of low birth weight, premature birth, and preeclampsia [6]. Hormonal changes during this period might also lead to the gingiva's sensitivity and inflammation; therefore, pregnant women brush their teeth and use dental floss less frequently, finally leading to microbial plaque formation on the teeth [2]. According to previous studies, there is a strong correlation between Streptococcus mutans counts in pregnant women and caries experience in their children. In other words, active dental caries in association with a high S. mutans counts might be transmitted from the mother to the infant, leading to carious lesions during early life. It is necessary to control a pregnant mother's oral plaque and decrease her oral S. mutans counts to decrease oral contamination risk in the child and prevent dental caries [7].

George et al. [8] evaluated the views of healthcare providers for pregnant women about the orodental health during pregnancy in Australia and concluded that pregnant mothers' knowledge about their oral health and the importance of their oral health during pregnancy was inadequate.

Nagarajapa et al. [9] evaluated the orodental health in newborns and their mothers' knowledge, attributes, and behavior in Udaipur, India, and reported that mothers with low educational levels had poor knowledge and attitudes toward their children's orodental health. However, mothers with high educational levels exhibited positive attitudes towards orodental health and better performance concerning their children's dental care.

Mani et al. [10] evaluated the parents' attitudes towards the prevention of orodental diseases in children in Malaysia in 120 parents with children $<2$ years of age, concluding that $60.8 \%$ of parents had positive attitudes towards proper nutrition and $1.96 \%$ had positive attitudes towards routine examinations by dentists as a means of preventing dental caries in children.

Chu [11] evaluated 600 mothers with preschool children in Hong Kong and reported that $10 \%$ of the mothers had poor knowledge, $51 \%$ had moderate knowledge, and $39 \%$ had proper knowledge about children's orodental health.

Since no study is available on pregnant women's knowledge about their children's orodental health, the present study aimed to evaluate pregnant women's knowledge about their children's orodental heath in their first pregnancy. The null hypothesis stated that pregnant women have a high level of knowledge about their children's orodental health in their first pregnancy.

\section{Materials And Methods}

The present cross-sectional/analytical study evaluated pregnant women referring to private obstetrics offices and clinics in Isfahan. Based on the inclusion criteria, pregnant women in their first pregnancy, who were in their second and third trimesters, and interested in taking part in the study, were included. Questionnaires in which $<20 \%$ of the questions had been replied were excluded. 
The samples consisted of 200 pregnant women who were selected using a two-stage random clustered sampling technique. To select the private offices and clinics, of 15 urban districts in Isfahan, seven districts were selected using the cluster sampling method, and then one clinic and two offices were randomly selected from each cluster (the selected district) by numbering them. The pregnant women in each office or clinic were selected using a convenient non-random technique, and the questionnaires were distributed among them and collected immediately after they were completed.

The questions were prepared in the form of a questionnaire to evaluate pregnant women's knowledge about their children's orodental health. The questions were extracted from similar studies and translated. In designing the questionnaire questions, an attempt was made to observe the principles for designing questionnaires used to determine awareness and knowledge. For example, the questions were written in a manner not to induce the correct response. The questionnaire was submitted to five professors in the Pediatric Department to ensure its face and content validity. Each professor was asked to score each question as follows for rating each question in terms of its necessity: Necessary: 1, Useful but unnecessary: 2, Unnecessary: 3 .

Besides, the professors were asked to make suggestions about each question if they wanted to. After evaluating the professors' views, questions with a score of 2 or 3 were eliminated or revised based on the professors' views. Then the questions' content validity ratio (CVR) was calculated, and questions with a CVR of $<0.42$ were eliminated [12]. Finally, the professors' opinions were asked about the face validity of the questionnaire.

To evaluate the questionnaire's reliability, it was submitted to 30 pregnant women in a pilot study, and Cronbach's alpha was calculated. Questions with a Cronbach's alpha of $<0.7$ were eliminated; the overall Cronbach's alpha was then calculated, which was $>0.7$. Therefore, its reliability was confirmed, too [13].

The final approved questionnaire consisted of three questions on demographic data, including age, educational level, and economic status, and 24 questions on the awareness about oral health and prevention of dental caries (four multiple-choice questions with four choices, and 20 questions with replies running as correct/incorrect/I do not know).

Concerning the mothers' economic status, their personal views and appraisal of their economic status were accepted, and their opinions about the family's economic status were categorized into four levels of low, moderate, good, and excellent.

After confirming the questionnaire's validity and reliability, the questionnaire was distributed among the pregnant women in private offices and clinics and collected after they were completed. Informed consent was obtained from all subjects.

The data on the questionnaire's main questions were coded and scored, with zero (I do not know, incorrect) or 1 (correct). Finally, the score range for knowledge questions was $0-24$. The scores were categorized as follows: 0-8: poor knowledge, 9-16: moderate knowledge, 17-24: high knowledge. 
The data were analyzed with SPSS 22. Means, standard deviations, frequencies, and frequency percentages were used to report descriptive statistics. Pearson's and Spearman's correlation coefficients were used for inferential statistics. Statistical significance was set at $P<0.05$ in all the analyses.

\section{Results}

The present study aimed to evaluate pregnant women's knowledge about their children's orodental heath during their first pregnancy. The subjects were selected from those referring to private prenatal offices and clinics in Isfahan.

According to Table 1 , the mean age of the present study subjects was $25.28 \pm 4.79$ years, with a range of $17-42$ years. The majority of the subjects were in the $20-25$ and $26-30$ years age groups, with $34.5 \%$ and $32 \%$, respectively.

Table 1

Descriptive data of the mothers' age in the present study

\begin{tabular}{|c|c|c|c|c|}
\hline \multirow[t]{2}{*}{ Mother's age } & Min & Max & Mean & SD \\
\hline & 17 & 42 & 25.28 & 4.79 \\
\hline Age group & \multicolumn{2}{|c|}{ Frequency } & \multicolumn{2}{|c|}{ Percentage } \\
\hline$<20$ & \multicolumn{2}{|l|}{39} & \multicolumn{2}{|l|}{$19.5 \%$} \\
\hline $25-20$ & \multicolumn{2}{|l|}{69} & \multicolumn{2}{|l|}{$34.5 \%$} \\
\hline $30-26$ & \multicolumn{2}{|l|}{64} & \multicolumn{2}{|l|}{$32 \%$} \\
\hline $35-31$ & \multicolumn{2}{|l|}{23} & \multicolumn{2}{|l|}{$11.5 \%$} \\
\hline$>35$ & \multicolumn{2}{|l|}{5} & \multicolumn{2}{|l|}{$2.5 \%$} \\
\hline
\end{tabular}

Table 2 presents the frequency distributions of pregnant women's educational levels in the present study. The majority of the subjects were high school graduates $(69,34.5 \%)$, and only one was illiterate. 
Table 2

Frequency distribution of mothers' educational level in the present study

\begin{tabular}{|lll|}
\hline Mother's educational level & Frequency & Percentage \\
\hline Illiterate & 1 & $0.5 \%$ \\
\hline Some high school education & 37 & $18.5 \%$ \\
\hline High school graduate & 69 & $34.5 \%$ \\
\hline Bachelor's degree & 57 & $28.5 \%$ \\
\hline Masters' degree & 24 & $12 \%$ \\
\hline Doctorate & 12 & $6 \%$ \\
\hline Total & 200 & $100 \%$ \\
\hline
\end{tabular}

Table 3 presents the frequency distributions of the economic status of the families. Based on the mothers' self-reports, $48.5 \%$ of the families had good economic status, and only $2.5 \%$ had low economic status.

Table 3

Frequency distribution of the family's economic status in the present study

\begin{tabular}{|lll|}
\hline Economic status & Frequency & Percentage \\
\hline Low & 5 & $2.5 \%$ \\
\hline Moderate & 73 & $36.5 \%$ \\
\hline Good & 97 & $48.5 \%$ \\
\hline Excellent & 25 & $12.5 \%$ \\
\hline Total & 200 & $100 \%$ \\
\hline
\end{tabular}

Table 4 presents the mean scores of pregnant women's knowledge domains in their first pregnancy about children's orodental health. As explained previously, mothers' knowledge about children's orodental health consisted of five domains, and all the questions were scored 0 (incorrect, I do not know) and 1 (correct). The awareness about 'children's orodental health' domain contained questions 7,8 , and 9 , and awareness of 'factors affecting children's orodental health problems' consisted of questions 17-24. The awareness of 'the factors affecting dental caries in children' consisted of questions $10-15,25$, and 27 . The awareness of 'prevention and dental treatments' consisted of questions 6,16 , and 26 , and finally, awareness of the 'proper time for dental visits' consisted of questions 4 and 5 . All the questions were scored using the 0 and 1 codes; then, the scores were divided by the number of questions in each domain to achieve the final score 
in each domain, which was a score between 0 and 1 . Mean scores close to 0 indicated improper or low knowledge level, and mean scores close to 1 indicated that the mother had proper knowledge. 
Table 4

Frequency distribution of the responses to the questions, and the means and standard deviations of

\begin{tabular}{|c|c|c|c|c|c|c|c|c|}
\hline \multirow[t]{2}{*}{ Domain } & \multirow[t]{2}{*}{ Questions } & \multicolumn{3}{|c|}{ Response } & \multirow[t]{2}{*}{ Mean } & \multirow[t]{2}{*}{ SD } & \multirow[t]{2}{*}{ Mean } & \multirow[t]{2}{*}{ SD } \\
\hline & & $\begin{array}{l}\text { Correct } \\
\text { (Score } \\
=1 \text { ) }\end{array}$ & $\begin{array}{l}\text { Incorrect } \\
(\text { Score = } \\
2)\end{array}$ & $\begin{array}{l}\text { Do not } \\
\text { know } \\
\text { (Score } \\
=0)\end{array}$ & & & & \\
\hline \multirow[t]{2}{*}{$\begin{array}{l}\text { Awareness } \\
\text { of the } \\
\text { proper } \\
\text { time to } \\
\text { refer to a } \\
\text { dentist }\end{array}$} & $\begin{array}{l}\text { In which } \\
\text { pregnancy } \\
\text { trimester are } \\
\text { dental procedures } \\
\text { permissible? }\end{array}$ & $\begin{array}{l}37 \\
(18.5 \%)\end{array}$ & $\begin{array}{l}61 \\
(30.5 \%)\end{array}$ & $\begin{array}{l}102 \\
(51 \%)\end{array}$ & 0.19 & 0.39 & 0.157 & 0.295 \\
\hline & $\begin{array}{l}\text { At what age a } \\
\text { baby's first dental } \\
\text { visit is } \\
\text { recommended? }\end{array}$ & $\begin{array}{l}25 \\
(12.5 \%)\end{array}$ & $\begin{array}{l}108 \\
(54 \%)\end{array}$ & $\begin{array}{l}67 \\
(33.5 \%)\end{array}$ & 0.13 & 0.33 & & \\
\hline \multirow[t]{3}{*}{$\begin{array}{l}\text { Awareness } \\
\text { of } \\
\text { children's } \\
\text { orodental } \\
\text { health }\end{array}$} & $\begin{array}{l}\text { At what age } \\
\text { should a baby's } \\
\text { teeth begin to be } \\
\text { brushed? }\end{array}$ & $\begin{array}{l}71 \\
(35.5 \%)\end{array}$ & $\begin{array}{l}96 \\
(48 \%)\end{array}$ & $\begin{array}{l}30 \\
(15.5 \%)\end{array}$ & 0.36 & 0.48 & 0.442 & 0.301 \\
\hline & $\begin{array}{l}\text { During the } \\
\text { infancy, a clean } \\
\text { wet piece of } \\
\text { gauze can be } \\
\text { used to clean the } \\
\text { baby's teeth after } \\
\text { breastfeeding. }\end{array}$ & $\begin{array}{l}121 \\
(605 \%)\end{array}$ & $\begin{array}{l}55 \\
(27.5 \%)\end{array}$ & $\begin{array}{l}24 \\
(12 \%)\end{array}$ & 0.61 & 0.49 & & \\
\hline & $\begin{array}{l}\text { The mother's oral } \\
\text { hygiene status } \\
\text { during pregnancy } \\
\text { and after it does } \\
\text { not affect the } \\
\text { baby's oral health } \\
\text { status. }\end{array}$ & $\begin{array}{l}71 \\
(35.5 \%)\end{array}$ & $\begin{array}{l}89 \\
(44.5 \%)\end{array}$ & $\begin{array}{l}40 \\
(20 \%)\end{array}$ & 0.35 & 0.48 & & \\
\hline \multirow[t]{3}{*}{$\begin{array}{l}\text { Awareness } \\
\text { of } \\
\text { children's } \\
\text { dental } \\
\text { caries }\end{array}$} & $\begin{array}{l}\text { Breastfeeding } \\
\text { and milk bottle } \\
\text { feeding during } \\
\text { night results in } \\
\text { dental caries. }\end{array}$ & $\begin{array}{l}100 \\
(50 \%)\end{array}$ & $\begin{array}{l}53 \\
(25.5 \%)\end{array}$ & $\begin{array}{l}47 \\
(23.5 \%)\end{array}$ & 0.50 & 0.50 & 0.375 & 0.205 \\
\hline & $\begin{array}{l}\text { Sharing a spoon } \\
\text { by the mother } \\
\text { and the baby } \\
\text { results in better } \\
\text { rapport between } \\
\text { them. }\end{array}$ & $\begin{array}{l}53 \\
(26.5 \%)\end{array}$ & $\begin{array}{l}104 \\
(52 \%)\end{array}$ & $\begin{array}{l}43 \\
(21.5 \%)\end{array}$ & 0.26 & 0.44 & & \\
\hline & $\begin{array}{l}\text { Untreated dental } \\
\text { caries in the } \\
\text { mother's oral } \\
\text { cavity can lead to }\end{array}$ & $\begin{array}{l}64 \\
(32 \%)\end{array}$ & $\begin{array}{l}97 \\
(48.5 \%)\end{array}$ & $\begin{array}{l}39 \\
(19.5 \%)\end{array}$ & 0.32 & 0.47 & & \\
\hline
\end{tabular}


dental caries in

the child.

\begin{tabular}{|c|c|c|c|c|c|}
\hline $\begin{array}{l}\text { Giving water to } \\
\text { the baby after } \\
\text { breastfeeding } \\
\text { decreases the } \\
\text { dental caries rate. }\end{array}$ & $\begin{array}{l}126 \\
(63 \%)\end{array}$ & $\begin{array}{l}34 \\
(17 \%)\end{array}$ & $\begin{array}{l}40 \\
(20 \%)\end{array}$ & 0.63 & 0.48 \\
\hline $\begin{array}{l}\text { Drinking fruit } \\
\text { juice from a } \\
\text { bottle can result } \\
\text { in early childhood } \\
\text { caries. }\end{array}$ & $\begin{array}{l}83 \\
(41.5 \%)\end{array}$ & $\begin{array}{l}45 \\
(22.5 \%)\end{array}$ & $\begin{array}{l}72 \\
(36 \%)\end{array}$ & 0.42 & 0.49 \\
\hline $\begin{array}{l}\text { Iron drops cause } \\
\text { dental caries. }\end{array}$ & $\begin{array}{l}24 \\
(12 \%)\end{array}$ & $\begin{array}{l}138 \\
(69 \%)\end{array}$ & $\begin{array}{l}38 \\
(19 \%)\end{array}$ & 0.12 & 0.0 .33 \\
\hline $\begin{array}{l}\text { In which of the } \\
\text { following } \\
\text { situations is your } \\
\text { child more } \\
\text { strongly affected } \\
\text { by dental caries: } \\
\text { If (s)he eats } 10 \\
\text { chocolate a day } \\
\text { at the same time } \\
\text { or } 10 \text { chocolates } \\
\text { a day one by one } \\
\text { with intervals } \\
\text { during the day? }\end{array}$ & $\begin{array}{l}50 \\
(25 \%)\end{array}$ & $\begin{array}{l}94 \\
(47 \%)\end{array}$ & $\begin{array}{l}56 \\
(28 \%)\end{array}$ & 0.25 & 0.43 \\
\hline $\begin{array}{l}\text { Milk teeth do not } \\
\text { require } \\
\text { restoration } \\
\text { because they } \\
\text { shed } \\
\text { spontaneously. }\end{array}$ & $\begin{array}{l}98 \\
(49 \%)\end{array}$ & $\begin{array}{l}87 \\
(43.5 \%)\end{array}$ & $\begin{array}{l}15 \\
(7.5 \%)\end{array}$ & 0.49 & 0.50 \\
\hline
\end{tabular}




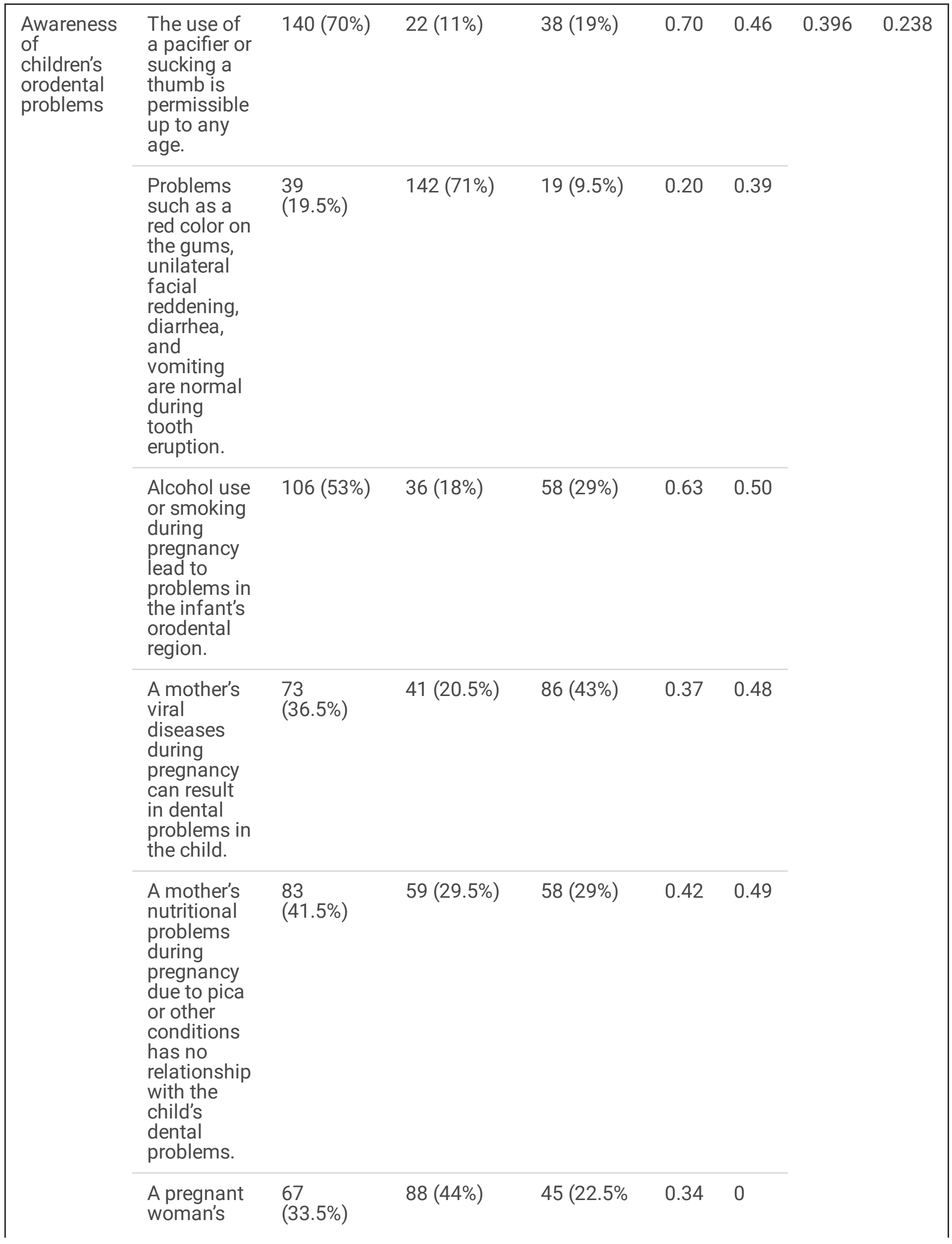




\begin{tabular}{|c|c|c|c|c|c|c|c|c|}
\hline & \multicolumn{6}{|l|}{$\begin{array}{l}\text { orodental } \\
\text { problems } \\
\text { might lead } \\
\text { to } \\
\text { premature } \\
\text { delivery. }\end{array}$} & & \\
\hline & $\begin{array}{l}\text { It is not } \\
\text { normal for } \\
\text { the baby's } \\
\text { first tooth } \\
\text { not to erupt } \\
\text { before } 6 \\
\text { months of } \\
\text { age. }\end{array}$ & $54(27 \%)$ & $81(5 / 40 \%)$ & $65(5 / 32 \%)$ & 0.27 & 0.45 & & \\
\hline & $\begin{array}{l}\text { Premature } \\
\text { birth might } \\
\text { cause } \\
\text { dental } \\
\text { problems in } \\
\text { the child. }\end{array}$ & $63(5 / 31 \%)$ & $81(5 / 40 \%)$ & $56(28 \%)$ & 0.32 & 0.47 & & \\
\hline \multirow[t]{3}{*}{$\begin{array}{l}\text { Awareness } \\
\text { of } \\
\text { prevention } \\
\text { and dental } \\
\text { treatments }\end{array}$} & $\begin{array}{l}\text { When } \\
\text { should } \\
\text { preventive } \\
\text { measures } \\
\text { for a child's } \\
\text { orodental } \\
\text { problems } \\
\text { begin? }\end{array}$ & $34(17 \%)$ & $115(5 / 57 \%)$ & $51(5 / 25 \%)$ & 0.17 & 0.38 & \multirow[t]{3}{*}{0.315} & \multirow[t]{3}{*}{0.347} \\
\hline & $\begin{array}{l}\text { The use of } \\
\text { xylitol- } \\
\text { containing } \\
\text { chewing } \\
\text { gums } \\
\text { during } \\
\text { pregnancy } \\
\text { help } \\
\text { decrease } \\
\text { dental } \\
\text { caries in } \\
\text { the mother } \\
\text { and child. }\end{array}$ & $64(32 \%)$ & $30(15 \%)$ & $106(53 \%)$ & 0.32 & 0.47 & & \\
\hline & $\begin{array}{l}\text { Fluoride } \\
\text { therapy at } \\
18-24 \\
\text { months of } \\
\text { age helps } \\
\text { decrease } \\
\text { dental } \\
\text { caries. }\end{array}$ & $88(44 \%)$ & $32(16 \%)$ & $80(40 \%)$ & 0.44 & 0.50 & & \\
\hline
\end{tabular}

Table 4 shows that the mothers' awareness about 'the child's orodental health' in awareness about 'cleaning the gums after breastfeeding' with a mean of $0.61 \pm 0.49$ was the highest. Besides, 'awareness of 
children's orodental problems' in the domain 'the adverse effect of pacifiers or thumb sucking at all ages' was the highest with a mean score of $0.7 \pm 0.46$. In the domain 'awareness of children's dental caries', the mothers' awareness of 'a decrease in dental caries rate due to giving water to the child after giving it milk' was the highest with a mean score of $0.63 \pm 0.48$. Also, 'awareness of prevention and dental treatments' in terms of the 'use of fluoride' was the highest with a mean score of $0.44 \pm 0.50$. Finally, 'awareness of the proper time to visit a dentist' at 'the proper time for children's non-emergency dental procedures' was the highest with a mean score of $0.19 \pm 0.39$. In general, the highest and lowest knowledge was related to the children's orodental health and the proper time to refer to a dentist, with mean scores of $0.442 \pm 0.301$ and $0.157 \pm 0.255$, respectively.

An attempt was then made to calculate the overall score instead of matching the study domains and evaluating each domain's overall mean score. Table 5 presents the results of this evaluation, providing the minimum and maximum scores, means, and standard deviations of mothers' knowledge in general and in each domain.

Table 5

The mean scores of mothers' knowledge about children's orodental health in terms of demographic characteristics

\begin{tabular}{|lllll|}
\hline Mother's awareness & Min & Max & Mean & SD \\
\hline Overall awareness & 1 & 22 & 8.66 & 4.53 \\
\hline Awareness of the proper time to refer to a dentist & 0 & 2 & 0.31 & 0.59 \\
\hline Awareness of children's orodental health & 0 & 3 & 1.32 & 0.89 \\
\hline Awareness of children's dental caries & 0 & 7 & 2.99 & 1.64 \\
\hline Awareness of children's orodental problems & 0 & 8 & 3.16 & 1.90 \\
\hline Awareness of prevention and dental treatments & 0 & 3 & 1.04 & 0.94 \\
\hline
\end{tabular}

Based on Table 5, the mothers' knowledge about 'children's orodental health' had a mean score of $1.32 \pm 0.89$. Besides, 'awareness of children's orodental problems' had a mean score of $3.16 \pm 1.90$. The mean score of 'awareness of children's dental caries' was $2.99 \pm 1.64$. Also, the mean score of 'awareness about prevention and dental treatments' was 1.04 \pm 0.94 . Finally, 'the mean score of 'awareness of the proper time to refer to a dentist' was $0.31 \pm 0.59$. In addition, since a total of 24 questions were used to evaluate the mothers' overall knowledge, the score range of knowledge was $0-24$, and the mean score of 'overall knowledge of mothers about children's orodental health' was $8.66 \pm 4.53$.

Besides, according to Figure1, the overall knowledge level of $82(41 \%)$ mothers about children's orodental health was moderate; 109 (54.5\%) of the mothers had poor knowledge, and only 9 (4.5\%) had proper knowledge. 
Finally, since it is possible for epidemiologic factors, including age, educational levels, and the family's economic status, to affect mothers' knowledge, in this section, the relationship between these factors and the overall knowledge scores of the mothers about children's orodental health was evaluated. The results are presented in Table 6, according to which there were significant and direct relationships between mothers' age $(P<0.001 r=0.288)$ and educational level $(P<0.001, r=0.497)$ and the family's economic status $(P=0.10 r=0.182)$ and the mothers' knowledge about their children's orodental health.

Table 6

Comparison of mean scores of mothers' overall knowledge about children's orodental health in terms of demographic characteristics

\begin{tabular}{|lll|}
\hline Factors & Overall awareness & \\
\hline Mother's age & Spearman's correlation coefficient & 0.288 \\
\cline { 2 - 3 } & Sig. & $<0.001$ \\
\hline Mother's educational level & Spearman's correlation coefficient & 0.497 \\
\cline { 2 - 3 } & Sig. & $<0.001$ \\
\hline Family's economic status & Spearman's correlation coefficient & 0.182 \\
\cline { 2 - 3 } & Sig. & $<0.010$ \\
\cline { 2 - 3 }
\end{tabular}

\section{Discussion}

The overall awareness of pregnant women about children's orodental health was low in their first pregnancy. Therefore, the null hypothesis of the study was rejected.

Since children's behaviors during the early days of life form their lifestyle and attitudes in adulthood and considering the role of deciduous teeth in children's general health, increasing the knowledge of breastfeeding mothers has a critical role in decreasing dental caries rate in the community. Therefore, parents, especially mothers, have a pivotal role in their children's orodental health, and their awareness can establish healthy behaviors in their children [3]. In the present study, pregnant women's awareness was evaluated in five domains, including awareness of children's orodental health, awareness of children's orodental problems, awareness of children's dental caries, awareness of prevention and dental treatments, and awareness of the proper time to refer to a dentist. The highest awareness was recorded in the domain on children's orodental health, and the lowest was recorded in awareness about the proper time to refer to a dentist.

Determining the mean awareness score of mothers during their first pregnancy about children's orodental health showed that the mean score on 'children's orodental health' was $0.442 \pm 0.301$; i.e., $>50 \%$ of the mothers had proper knowledge in this domain or had no knowledge, with the least frequency of misinformation. Consistent with the present study, studies by Chu et al. [11] and Lloyd et al. [14] showed a moderate level of mothers' awareness about children's orodental health, which might be explained because 
studies in this field have shown that cultural factors and the geographic location do not affect the results, and mothers exhibited a moderate level of awareness about children's orodental health.

The mean score of the mothers' awareness about 'children's orodental problems' was $0.936 \pm 0.238$. Besides, the mothers' awareness about the adverse effects of alcohol use and cigarette smoking during pregnancy and the use of pacifiers or thumb sucking on children's orodental problems was higher than other fields, and the lowest awareness related to the effect of mothers' viral diseases during pregnancy on children's dental problems. Also, concerning tooth eruption, the mothers exhibited the highest misinformation. Consistent with the present study, a study by Retnakumari et al. [15] showed a significant relationship between sleeping with a pacifier and the incidence of dental problems in children, with the mothers participating in the study being aware of the problem. Therefore, the mothers in both these studies were aware of children's orodental problems and the etiologic factors involved and were able to help improve their children's orodental health by decreasing the factors responsible for these problems. Therefore, it might be concluded that mothers can help prevent and solve their children's orodental problems by gaining knowledge about these problems and taking the necessary precautions.

The mothers' mean awareness score for 'children's dental caries' was $0.375 \pm 0.205$. Evaluation of the questions in this domain showed that the mothers were aware that breastfeeding and use of a milk bottle nightlong led to dental caries in children and giving water to the child after feeding him/her with milk and attention to the restoration and preservation of deciduous teeth can decrease dental caries in children. In this context, Togoo et al. [16] showed that almost half of the mothers fully agreed that giving milk to the child immediately before sleep causes dental caries. In contrast, the participants had low awareness and wrong beliefs about sharing a spoon between the mother and infant and the adverse effects of iron drops on children's dental caries. Mazaheri et al. [17] reported that mothers in Shiraz believed that iron drops were the primary etiologic agent for dental caries. In addition, they provided correct responses about the deciduous teeth' lack of need for restoration because they shed spontaneously, which is different from a study by Sultan et al. [18]

The mothers' mean awareness score about 'prevention and dental treatments' was $0.315 \pm 0.347$. On the other hand, the frequency distribution of the responses to the questions in this domain showed that mothers had moderate awareness about fluoride therapy at 18-24 months of age; however, they had misinformation and insufficient knowledge about preventive measures for dental caries and the effect of using xylitol chewing gums during pregnancy. Consistent with the present study, two studies by Thakare et al. [19] and Mounissamy et al. [20] showed that mothers were unaware of the benefits of oral hygiene habits and preventive measures and dental treatments. Besides, a study by Mani et al. [10] in Malaysia showed that only $1.96 \%$ of parents had positive attitudes towards routine examinations by dentists to prevent children's dental caries. However, the study by Mazaheri et al. [17] showed that more than half of the mothers of 1 to 3-year-old children in Shiraz had proper knowledge about the therapeutic use of fluoride, such as fluoride varnishes in children, which is different from the present study. Such a discrepancy might be attributed to the statuses of the mothers evaluated, the city they resided in, etc. because in the present study, only pregnant women in their first pregnancy were evaluated. Mothers with several pregnancies and raising their children might have exhibited different knowledge levels because 
their experience would increase to help them gain adequate information in raising their children. Mothers in their first pregnancy might not have adequate knowledge in this field. Therefore, it is necessary to train these women during pregnancy and provide them with information in this field. Educating children in dental and oral care and observing oral hygiene by young children is considered an investment in children's health with long-term benefits. Therefore, mothers must pay adequate attention to these subjects and issues and gain adequate knowledge because parents, especially mothers, have a crucial role in improving their children's oral hygiene habits. Previous studies have also provided ever-increasing evidence about bacteria's role, especially Streptococci, in inducing dental caries. Streptococcus mutans can produce large amounts of acid, is highly durable in acidic environments, and is mainly responsible for dental caries in human beings. This bacterial species is more prevalent in pregnant women, which is very important because pregnant women can transmit infections to the fetus, causing unfavorable complications. Therefore, preventive measures should be adopted in pregnant women.

The mothers' score on awareness about 'the correct time to refer to a dentists' was $0.157 \pm 0.295$, with many mothers having misinformation or inadequate knowledge in this respect.

The mothers in this study had the least awareness about the correct time to take their children to a dentist. Mazaheri et al. [17] reported that only $8.9 \%$ of mothers were aware that a dentist should examine their infants before one year of age, and most mothers were not aware of this, consistent with studies by Thakare et al. [19] and Mounissamy et al. [20].

Besides, the mothers participating in the present study were unaware of the proper pregnancy trimester during which non-emergency dental procedures could be carried out, consistent with studies by Kandan et al. [21] and Gonik et al. [22]. Considering these two studies and since pregnancy might increase susceptibility to gingival diseases and dental caries and by considering the misinformation, many pregnant women believe that routine dental treatments are dangerous to the fetus, and it is necessary to provide them with the necessary information and ask them to refer to a dentist at the correct time by the care providers. This can decrease the complications of gingival diseases, including increased risk of low birth weight.

The mother's mean score on their 'overall awareness of children's orodental health' was $8.66 \pm 4.33$. Consistent with the present study, Mohebbi et al. [5] reported mothers' low awareness despite using various data sources about children's oral health. Besides, studies by George et al. [8] and Pothnie et al. [23] are consistent with the present study.

Torabi et al. [24] evaluated the awareness and performance of mothers concerning children's orodental health. A total of 400 mothers were included in the study in Kerman. The results showed that mothers' awareness about children's orodental health was favorable, which is different from the present study results. Such a discrepancy might be attributed to differences in sample sizes between the two studies and inattention to the number of pregnancies.

Finally, evaluating the relationship between demographic factors, such as age, educational level, and family's economic status with mothers' scores of overall knowledge about children's orodental health, 
showed a direct and significant relationship between mothers' age and their knowledge about children's orodental health. However, Nazari et al. [25] showed no significant relationship between mothers' age and their knowledge and attitude scores about children's orodental health. Although the results of the studies above are different from the present study concerning the results of the present study, it might be pointed out that since younger mothers have inadequate knowledge about children's orodental health and the relevant care due to their inadequate experience, mother's aging has resulted in increased awareness about their children's orodental health.

Furthermore, mothers' educational level exhibited a direct and significant relationship with their knowledge about children's orodental health. Nagarajapa et al. [9] reported from India that mothers with low educational level had poor knowledge and attitudes towards children's orodental health; in contrast, mothers with higher educational levels exhibited positive attitudes towards children's orodental health and had good performance concerning the care of their children's teeth, with a significant relationship between knowledge and mothers' educational level. To explain this finding, education is one of the most critical socio-economic parameters that affect knowledge, attitudes, and the necessary skills to adopt proper health-related behaviors. Therefore, educated parents are more sensitive about their children's health, resulting in more regular visits to evaluate health status. The family's economic status was significantly related to the mothers' overall knowledge about their children's orodental health. Consistent with the present study, Kallestal et al. [26] reported a direct correlation between the economic status, gender, residential area, ethnicity, social status, and parents' occupation with the parents' performance concerning their children's orodental health. To explain this finding, there was a significant relationship between the economic status and the overall awareness of mothers about children's orodental health. Besides, according to previous studies, a better economic status of mothers and their employment results in their higher rate of communication with other community members and their access to data sources and better education, increasing their awareness and improving their performance concerning their children's orodental health.

The present study evaluated only pregnant women referring to the private obstetrics offices and clinics in Isfahan, which is considered one of the present study's limitations. Since the data collection tool in the present study was a questionnaire, some participants might not have provided accurate responses to the same questions. It is suggested that similar studies be carried out in different cities of the country with larger sample sizes to evaluate whether these findings are valid in other parts of the country or not. Since many children $<6$ years of age are looked after in kindergartens, it is suggested that a similar study be carried out to evaluate the kindergarten nurses' awareness of children's orodental health.

\section{Conclusion}

According to the present study results, the mothers had a low knowledge level about children's orodental health. Besides, there were direct and significant relationships between the mothers' age and educational level and the family's economic status, and mothers' awareness about children's orodental health. Therefore, it is necessary to hold educational workshops and provide useful data for mothers before pregnancy or during pregnancy. 


\section{Abbreviations}

CVR: content validity ratio

\section{Declarations}

\section{Ethics Approval and Consent:}

The study was performed in accordance with the Declaration of Helsinki and approved by the Ethics Committee of the Deputy Dean for Research, Isfahan University of Medical Sciences.

(IR.MUI.REC.1397.3.123)

Informed consent was obtained from participants.

\section{Consent for publication:}

Not applicable

\section{Availability of data and materials:}

All data generated or analysed during this study are included in this published article.

\section{Competing interests:}

The authors declare that they have no competing interests

\section{Funding:}

Grant Number from Isfahan university of medical sciences: 397123

\section{Authors' contributions:}

AE gathered the data and PG analyzed and interpreted the participant data. DT was a major contributor in designing and writing the manuscript. All authors read and approved the final manuscript.

\section{Acknowledgements:}

The authors would like to thank the Isfahan University of Medical Sciences for financial support.

\section{References}

1. Moghaddam LF, Vettore MV, Bayani A, Bayat AH, Ahounbar E, Hemmat M, Armoon B, Fakhri Y.The Association of Oral Health Status, demographic characteristics and socioeconomic determinants with Oral health-related quality of life among children: a systematic review and Meta-analysis. BMC Pediatr. 2020; 20(1):489. doi: 10.1186/s12887-020-02371-8. 
2. Shamsi M, Hidarnia A, Niknami S. A survey of oral health care behavior in pregnant women of Arak: Application of health belief model. J Mazandaran Univ Med Sci. 2012; 22(89): 104-15.

3. Mehdipour A, Montazeri Hedeshi R, Asayesh H, Karimi A, Omidi Kopayee R, Asgari H. Evaluation of knowledge, attitudes and performance of the parent of preschool and primary school children referred to health centers of Qom city about the importance of preserving primary teeth and its related factors, Iran. Qom Univ Med Sci J. 2016; 10(6): 94-105.

4. Bayat F, Karimi-Shahanjarini A, Bashirian S, Faradmal J. Assessment of Dental Care and its Related Barriers in Pregnant Women of Hamadan City. J Educ Community Health. 2016; 3(1): 20-7.

5. Ali M Al-Zahrani, Abdullah S Al-Mushayt, Meshari F Otaibi, Amjad H Wyne. Knowledge and attitude of Saudi mothers towards their preschool children's oral health. Pak J Med Sci. 2014; 30(4): 720-724. doi: $10.12669 /$ pjms.304.5069

6. Kazemi HH, Zeinalzadeh M, Farsam F, Khafari S, Matloobi N. Personal pregnant women report on oral health status and their relationship with oral and dental examinations. 2015; 18(186): 9-16.

7. Balan U, Gonsalves N, Jose M, Girish KL. Symptomatic changes of oral mucosa during normal hormonal turnover in healthy young menstruating women. J Contemp Dent Pract. 2012; 13(2): 178-81.

8. George A, Dahlen HG, Reath J, Ajwani S, Bhole S, Korda A, Chok HN, Miranda C, Villarosa A, Johnson $M$. What do antenatal care providers understand and do about oral health care during pregnancy: a cross-sectional survey in New South Wales, Australia. BMC Pregnancy Childbirth. 2016; 16(1): 382.

9. Nagarajappa R, et al. Infant oral health: Knowledge, attitude and practices of parents in Udaipur, India. Dental research journal. 2013; 10(5): 659.

10. Mani SA, John J, Ping WY, Ismail NM. Early Childhood Caries: Parent's Knowledge, Attitude and Practice Towards Its Prevention in Malaysia 2012. Oral Health Care Pediatric, Research, Epidemiology and Clinical Practices. London: InTech, 2012, p.51-57.

11. Chu $\mathrm{CH}, \mathrm{Ho} \mathrm{PL}$, Lo ECM. Oral health status and behaviors of preschool children in Hong Kong. BMC Public Health. 2012; 12: 767.

12. Lawshe $\mathrm{CH}$. A quantities approach to content validity. Person psychology. 1975:28(4): 563-75.

13. Helms JE, Henze KT, Sass TL, Mifsud VA. Treating Cronbach's alpha reliability coefficients as data in counseling research. The counseling psychologist. 2006; 34(5): 630-60.

14. Lloyd A. Maternal knowledge, attitudes and practices and health outcomes of their preschool-age children in urban and rural Karnataka, University of South Florida, India. 2009; 1(1): 22

15. Retnakumari N, Cyriac G. Childhood caries as influenced by maternal and child characteristics in preschool children of Kerala-an epidemiological study. Contemporary clinical dentistry. 2012; 3(1): 2.

16. Togoo RA, Luqman M, Al-Hammadi AA, Al-Rabai NA, Ahmasani SM, Al-Qahtani BD. Caregivers' knowledge, attitudes, and oral health practices for infants attending day-care centers in two cities in southern Saudi Arabia. Gulf Med. J. 2017; 6:35-41.

17. Mazaheri R, Feizi Najafi N, Ghaffari E, Alamdarloo Y, Ghazalgoo A. Knowledge, attitudes and performance of mothers of children aged 1-3 years regarding oral health and early childhood caries in Shiraz. J Isfahan Dent Sch. 2016; 12(3): 248-259. 
18. Sultan S, Ain TS, Gowhar O. Awareness of mothers regarding oral health of their children in Kashmir, India. Int J Contemp Med Res. 2016; 3: 2169-71.

19. Thakare VG, Krishnan CA, Chaware S. Parents' perceptions of factors influencing the oral health of their preschool children in Vadodara city, Gujarat: A descriptive study. European Journal of General Dentistry. 2012; 1(1): 44.

20. Mounissamy A, Moses J, Ganesh J, Arulpari M. Evaluation of parental attitude and practice on the primary teeth of their children in Chennai: A hospital survey. International Journal of Pedodontic Rehabilitation. 2016; 1(1): 10.

21. Kandan PM, Menaka V, Kumar RR. Oral health in pregnancy (guidelines to gynaecologists, general physicians \& oral health care providers). JPMA-Journal of the Pakistan Medical Association. 2011; 61(10): 1009.

22. Gonik B, Wilson E, Mayberry M, Joarder BY. Pregnant Patient Knowledge and Behavior Regarding Perinatal Oral Health. Am J Perinatol. 2017; 34(7): 663-667.

23. Rothnie JJ, Walsh CA, Wang MJ, Morgaine KC, Drummond BK. An exploratory study of pregnant women's knowledge of child oral health care in New Zealand. N Z Dent J. 2012 ;108(4): 129-33.

24. Torabi M, Shojaeipour R, Karimi afshar S, Shojaat M, Karimi afshar M, Mosharafian SH. Determining the level of knowledge and performance of parents in the field of oral health and oral health of 7-yearold children. Iranian Children's Dentistry Journal. 2013; 9(1): 21-28.

25. Nazari Z, Tagerpour M. Mothers' Awareness, regarding Orodental Health of their Children at age of 1-6 Years old in Shirvan. Journal of North Khorasan University of Medical Sciences. 2013 ;5: 979-986.

26. Källestål C, Dahlgren L, Stenlund H. Oral health behavior and self-esteem in Swedish adolescents over four years. Journal of adolescent health. 2006 ;38(5): 583-90.

\section{Figures}




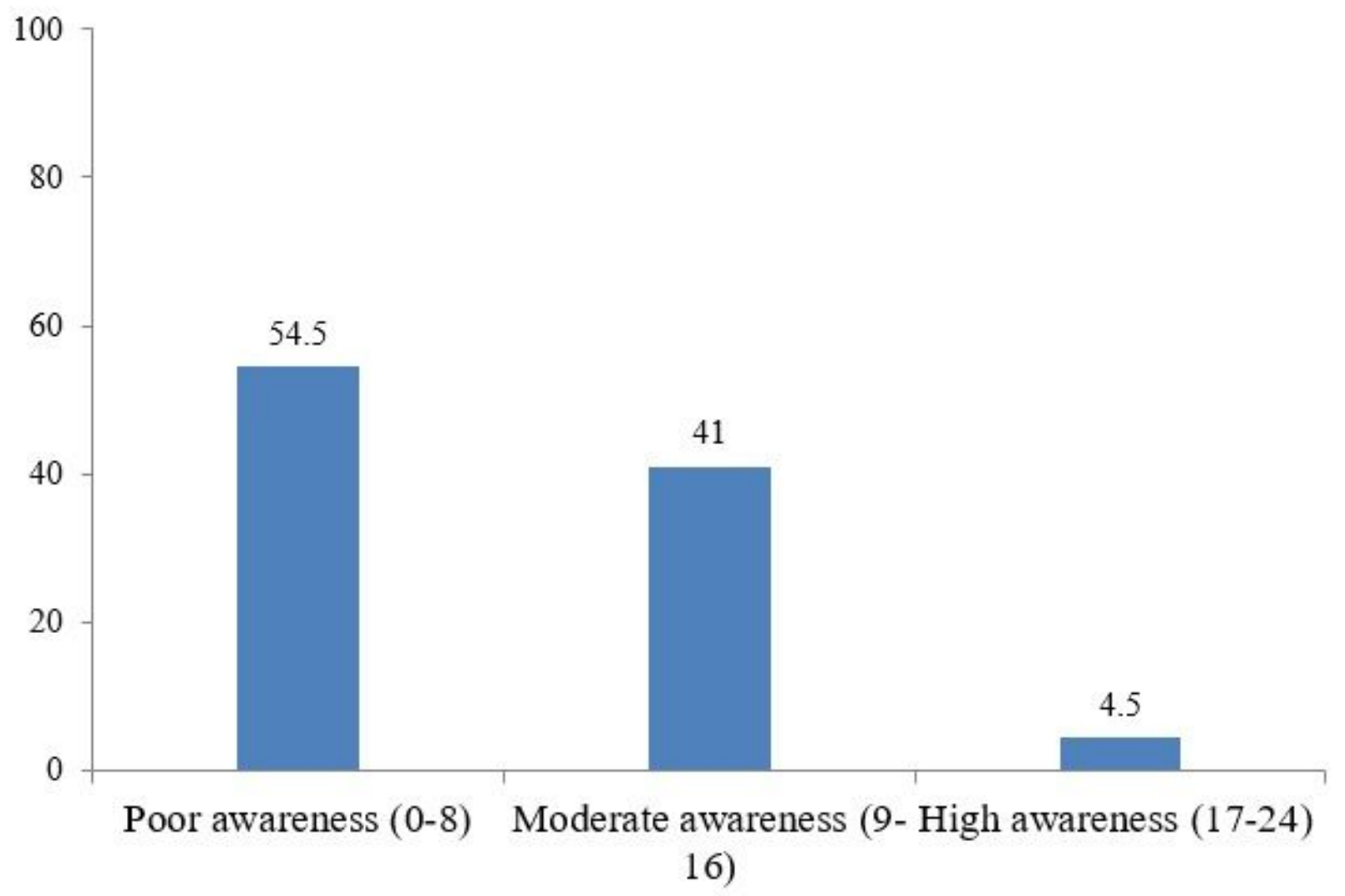

Figure 1

Frequency distribution of mothers' overall knowledge about children's oral health. 